\title{
Italian Jesuits and the Great War: Chaplains and Priest-Soldiers of the Province of Rome
}

\author{
Maria Paiano \\ University of Florence, Italy \\ maria.paiano@unifi.it
}

\begin{abstract}
This essay traces the history of the assistance afforded to soldiers by Italian military chaplains during First World War. It focuses on the Catholics' commitment to permeating the army, with the foundation of clubs and the printing of texts containing instructions and prayers for the spiritual training of enlisted men. These books show a more patriotic inspiration than their predecessors, because for the Roman Church conquering the army meant conquering the Italian unitary state. In particular, the article reconstructs the role of the Jesuit Carlo Massaruti, the author of a book for soldiers and promoter of an association for recruits before the war. The chaplains and priestsoldiers mobilized, however, were many and various. Their experience is highlighted in L'Eco dei nostrimilitari, a bulletin founded by the Roman province of the Society, which published the correspondence between the priests on the front and their provincial superiors. These letters furnish a vivid fresco of the work done by the Jesuits alongside the soldiers.
\end{abstract}

\section{Keywords}

Society of Jesus - World War I - Italian military chaplains - Pius X - Opera Massaruti religious books for soldiers - L'Eco dei nostri militari 
There are no specific studies on the history of Italian Jesuits during the First World War. ${ }^{1}$ Martina's volume on the history of the Italian Society from 1814 to 1983 offers a few brief remarks, highlighting their involvement in the Italian general mobilization in the spring of 1915 as chaplains or as priest-soldiers. ${ }^{2}$ Their involvement was the outcome of conflicting policies regarding the secularization of the state pursued by the new kingdom. ${ }^{3}$ Between 1869 and 1875, mandatory military service was extended to the clergy; ${ }^{4}$ between 1865 and 1878 , Italy abolished religious assistance to the national army and navy. ${ }^{5}$ On the other hand, during the 1911-12 war against the Ottoman Empire, it allowed chaplains to serve as volunteers in the medical support corps for the Italian soldiers in Libya. Moreover, on the eve of Italy's entry into the First World War, the chief of staff of the Royal Italian Army, Luigi Cadorna (1850-1928), reintroduced chaplains in all military units, and from then on every regiment had a Catholic chaplain. Other religious confessions had chaplains too, though less numerous (during the conflict Waldensians and Jews each had nine chaplains in total). This decision clearly had the goal of using religion as a means of promoting cohesion within the army and making soldiers more disciplined. The Holy See tried to lay down guidelines, which would make it possible for the church and the state to cooperate in regard to military chaplains. On June 1, 1915, a decree of the Consistorial Congregation appointed Angelo Bartolomasi (1869-1959), auxiliary bishop of Turin, as the general bishop of the Italian army and navy. He was to be the leader of all military chaplains, except for those who belonged to the Order of Malta. On June 27, the Italian government redefined Bartolomasi's appointment of and put him in charge of the religious ministry to the Italian military corps. He was to appoint new chaplains and to control their discipline, but, in practice, he controlled the moral and religious discipline of both Catholic chaplains and priest soldiers. ${ }^{6}$ The latter would usually

1 However, we can find a multitude of references to the Jesuits in Roberto Morozzo Della Rocca, La fede e la guerra: Cappellani militari e preti soldati (1915-1918) (Rome: Studium, 1980). On France, see Marie-Claude Flageat, Les jésuites français dans la Grande Guerre: Témoins, victimes, héros, apôtres (Paris: Cerf, 2008). On Ireland, see Damien Burke, Irish Jesuit Chaplains in the First World War (Dublin: Messenger, 2014).

2 Giacomo Martina, Storia della Compagnia di Gesù in Italia (1814-1983) (Brescia: Morcelliana, 2003), 255-57.

3 On the consequences of the religious politics of the Italian state for the Society, see Martina, Storia, $115-43$.

4 Maria Lupi, "Vescovi/1: dal 1848 alla fine del secolo," in Cristiani d'Italia, ed. Alberto Melloni (Rome: Treccani, 2011), 2:809-27, here 815-16; Maurilio Guasco, Storia del clero in Italia dall'Ottocento a oggi (Rome-Bari: Laterza, 1997), 79.

5 Morozzo della Rocca, Lafede, 7 .

6 Ibid., 8-11. 
serve in the medical corps if they had already been ordained, and in the fighting corps if they were still seminarians. They often offered the same moral support to the soldiers that the chaplains provided. ${ }^{7}$ The activity of the Jesuits who had been mobilized for the war should, therefore, be considered in this context, which involved all religious and secular Italian clergy. Thus, it makes little sense to study the chaplains' role separately from that of the priest-soldiers. The soldiers' pastoral care was delivered by both categories of military clergy, regardless of their religious order.

In this essay, I will investigate the case of the Jesuits of the province of Rome. ${ }^{8}$ I will do so by focusing on an important example of a military apostolate, the Opera Massaruti, and by examining the Jesuit internal bulletin, L'Eco dei nostri militari. Published from October 1915 to March 1918-and up until July 1918 with the title of Corrispondenza (provincia romana) - it included letters sent by Roman Jesuits at war to their brethren. On its first page one could usually read "private letter," "letter for private use only" or "manuscript for private use only." In other words, the writers' desire was to be read only within the small circle of the members of the Society who came from the same province. The scope of this essay is limited to the Roman province, first of all, because research regarding the Italian Jesuits during the First World War is still at an early stage; secondly, because it sheds light on the role of both Jesuit chaplains and priest-soldiers; thirdly, because through figures such as the Roman Jesuit Carlo Massaruti, the province can be seen as an important case study for the military apostolate in Italy during the early twentieth century. ${ }^{10}$

8 The Society in Italy was divided into five provinces: the Roman, Sicilian, and Neapolitan, and those of Turin, and of the Veneto. In 1978, they were united into one Italian province. The Eco was consulted at the Archivio della Provincia d'Italia della Compagnia di Gesù [Archives of the Italian Province of the Society of Jesus, Rome, hereafter AIPSJ]. Other Italian provinces printed a similar bulletin. Besides L'Eco, at the Archivum Romanum Societatis Iesu, Rome, one can consult also the Militia Christi (Sicilian Province, 1916-17) and Dal campo e dalla provincia (Neapolitan Province, 1915-18).

Massaruti was born in Rome in 1878 , and before secondary school he attended the Jesuit Istituto Massimo, where he would become close to the founder Massimiliano Massimo and to other Jesuits seconded from their associations. On November 12, 1898, he entered the novitiate at Castel Gandolfo and on July 14 was ordained. When he was fifty, he became ill with tuberculosis and died on August 6, 1930 at the novitiate in the Sanctuary of Galloro, Ariccia: see Giuseppe Massaruti, P. Carlo Massaruti della Compagnia di Gesù: Apostolo dei militari; Memoria del fratello Giuseppe (Isola del Liri: Macioce e Pisani, 1933); AIPSJ, Personal file of Carlo Massaruti (printed text): Parole dette dal Signor Ettore Albanesi in memoria del Padre Carlo Massaruti nella sede dell'Opera di Assistenza Religiosa per i Militari il 10 agosto 1930; AIPSJ, Il Padre Carlo Massaruti, in Notizie edificanti della 
The anticlerical political forces in Italy were worried by the mobilization of Catholics in the military pastoral service. La Civiltà cattolica, the periodical founded in $185^{\circ}$ as the organ of the Italian Society, took part in the discussion regarding the issue of religion in the army forces, maintaining similar positions to those expressed in many letters from Roman Jesuits during the war. For this reason, I begin my reconstruction by looking at the numbers of La Civiltà cattolica, the more so because it was very close to the positions of the Holy See itself.

\section{1 \\ La Civiltà cattolica and the Debate before the Great War}

Since the last decade of the nineteenth century, the period of resumption of colonial politics by the Prime Minister Francesco Crispi (1818-1901), Italian Catholics had asked to reintroduce military chaplains in the National Army and Navy and had founded associations for soldiers. Both conciliatories and intransigents had been persuaded of the importance of religious care for soldiers, but on different grounds. The former argued that religion would make the Army more efficient because it would strengthen soldiers' obedience to the higher ranks and the willingness to sacrifice one's life for the homeland. The latter also believed this, but insisted that the love for the motherland and military life should be rooted in Catholicism. For them, reintroducing religious assistance in the Army was the first step towards the return to a Catholic state and to a solution for the "Roman Question." For the intransigents, love for one's own country should always be subordinated to that of one's faith. Therefore, loyalty to the church should come before that owed to the state: Catholics should fight to make the Italian state a confessional one. ${ }^{11}$ These positions were aligned with those of both Pope Leo XIII (r.1878-1903) and Pius X (r.1904-14). In 1909, the latter beatified Joan d'Arc, presenting her as a model of true Christian patriotism and promoting the role of the sovereign pontiff as patron of international peace. Pius $\mathrm{x}$ believed that all forms of patriotism were good if they recognized religion and the pope's authority to judge controversies between peoples. True justice and not the alleged superiority of one nation over another would guide his judgement. ${ }^{12}$

Provincia romana per l'anno 1930, 141-47, offprint from the Bollettino degli alunni del Collegio Americano.

11 Maria Paiano, "Religione e patria negli opuscoli cattolici per l'esercito italiano: Il cristianesimo come scuola di sacrificio per i soldati," Rivista di storia del cristianesimo 8 (2011): 7-26.

12 Maria Paiano, "Chiesa cattolica e Unità d'Italia tra secolarizzazione della società e sacralizzazione della politica," in Cattolici e Unità d'Italia: Tappe, esperienze, problemi di un discusso percorso, ed. Maria Paiano (Assisi: Cittadella, 2012), 19-56, here $48-50$. 
The foundation of the first Italian Catholic military associations was accompanied by the printing of religious handbooks meant for soldiers, thus reviving a literary genre created by the Jesuits in the sixteenth century. Most of them were the expression of the intransigent viewpoint and would be seen as a threat by military authorities and some political parties. In 1910, a booklet asserting the superiority of the cross to the flag was confiscated in Brescia and the official who had disseminated it was punished. Members of Parliament accused Catholic associations of distributing the booklet and put a ban on religious publications in the military ${ }^{13}$ La Civiltà cattolica took part in the discussions that emerged from the parliamentary debate, denying any incompatibility between Christianity and military life, religion and the homeland, church and state. The review underlined the "advantages" of rooting military life, love for the homeland and the state, in the Catholic religion. It especially asserted that this was able to instill in individuals a sense of duty, obedience, discipline, and the spirit of sacrifice: all attitudes they considered necessary for making the Army more efficient, the state and society more solid. On the basis of these arguments, La Civiltà cattolica asserted that Catholic associations were not a threat to patriotism or Italian identity. With reference to the 1910 booklet, the review declared that the supremacy of the cross for a Christian did not imply that he would fight without a strong engagement to his country's flag. ${ }^{14}$

In so doing, La Civiltà cattolica was not only supporting a theoretical principle. Two of the Catholic associations mentioned in the parliamentary debate were linked to the Society. One was situated in a Jesuit house in Modena, the other in the Latin American Pius College in Rome. Information on the first association is very scarce, while it is known that the second would become very active during the Great War and continue its work after it. In 1930, when its Jesuit founder died, it took his name and became known as the Opera Carlo Massaruti.

The Opera Massaruti was founded at the beginning of the twentieth century. Though the Italian state denied them juridical recognition, the Jesuits tried to

13 Maria Paiano, “'Amate la religione e la patria con uno stesso amore': Declinazioni del patriottismo cattolico nei manuali religiosi per i soldati italiani tra Otto e Novecento," in Écrire l'histoire du christianisme contemporain: Autour de l'œuvre d'Étienne Fouilloux, ed. Annette Becker et al. (Paris: Karthala, 2013), 103-13.

14 [Antonio Lanza], "Lo spirito religioso nell'esercito," La Civiltà cattolica 66, no. 3 (1910): 19-38. See "L'intolleranza anticlericale e l'esercito," L'Osservatore romano (May 24, 1910), 1. 
reach through their apostolate different social milieus and categories of working men. ${ }^{15}$

Their work with soldiers began in 1905 in a Jesuit house at Prati of Castello and found a more definitive settlement in 1908 in the Latin American Pius College in Rome under the direction of Carlo Massaruti. It first reached out to the Carabinieri, but then rapidly spread to all of the military world. ${ }^{16}$ In a memorandum of 1918, Massaruti explained that his association organized regular religious services and offered a space where soldiers could read "improving publications," write letters to their parents, relax in a "wholesome" way through activities that did not go against Catholic morality. In the evening, they would hold religious meetings (with prayers, catechism, sacred songs) in a chapel specifically built for soldiers with the financial support of Pius $\mathrm{X}$, and inaugurated on Easter Sunday 1914. In the same document, Massaruti stated that his projects always had the consent of all his provincial superiors and local rectors. He also said that Pius $\mathrm{x}$ had encouraged him to enlarge the rooms dedicated to soldiers' meetings, maybe to contrast Protestant evangelization in the Italian Army (in the same period a Waldensian association for soldiers had been founded in Rome). During the war, the association also received the support of Benedict XV. ${ }^{17}$

According to his older brother Giuseppe, also a Jesuit, in 1910 Carlo's association was the object of anticlerical attacks causing attendance to fall off markedly: this was the same year in which Parliament criticized religious propaganda in the Army. To calm the controversy and to avoid disputes with the lay institutions (such as the non-denominational Casa del Soldato, that had been founded in Rome for the education of the soldiers), Carlo tried to give his association a strictly religious character. ${ }^{18}$ But he himself went beyond the regular activity of his association and visited garrison troops, military prisons, infirmaries, etc. ${ }^{19} \mathrm{He}$ also wrote a religious booklet for soldiers that he would usually distribute at every meeting, entitled Manuale religioso del soldato. The first edition of 1909 was dedicated to the Carabinieri, but many other editions were meant for all other military corps followed soon after, and it continued to be published during the war and even during the fascist regime. ${ }^{20}$

\footnotetext{
15 Martina, Storia, 243-49.

16 Il Padre Carlo Massaruti, 141.

17 AIPSJ, Opera Carlo Massaruti, 2nd file, Origini dell'Opera C. Massaruti, Carlo Massaruti, Pro Memoria dell'Opera Militare Collegio P. L. Americano - Roma, manuscript (probably between the end of 1918 and the beginning of 1919).

18 Massaruti, P. Carlo Massaruti, 28-34.

19 AIPSJ, Il Padre Carlo Massaruti, 142.

20 Massaruti, P. Carlo Massaruti, 30-31.
} 
It is important to examine the details of this text-at least of the 1913 and 1915 editions $^{21}$ - because it can help understand Massaruti's ideas on religion in the Army. The booklet's structure and contents were similar to the handbooks for soldiers printed in Italy in the second half of the nineteenth century (which in turn were similar to Il soldato cristiano, published by Antonio Possevino in 1569). It had three sections ("Duties and Practices of the Christian Soldier"; "Catechism Summary"; "Reminders to the Soldier") and it was meant to teach soldiers Christian morals and religious duties through reminders of traditional prayers and catechism, as well as the correct conduct to pursue in military life and at war, both considered dangerous for one's faith. By examining their conscience soldiers would understand what was righteous or wrongful behavior, such as visiting immoral places, dishonest actions, alcoholism, mistreating companions and offending superiors, but also reading "bad" propaganda opposing religion and the clergy, bad books and reviews, as well as hiding one's own faith. The latter were considered modern "sins" of the age of secularization, and the concept of "sin" itself was extended to the public disclaiming of one's own belief. ${ }^{22}$ The booklet's main concern was to protect the soldiers' faith from the "dangerous" world of military life.

In this regard, some specific prayers in the booklet are very significant. One was to be said after Holy Communion, asking God to give "the courage to win over 'human respect."'23 In another prayer St. Martin, the Army's protector, was asked to intercede with Christ to have the soldiers receive "the same strength and courage he [Martin] had in battle and a heart without fear of accepting one's own Christian faith." The soldier should also ask the saint to protect the Army, make it really "heroic," and make sure "that one day Catholic soldiers will be crowned in heaven in the glory of the eternal King Jesus Christ." ${ }^{24}$ Heaven was only invoked for Catholic soldiers, taking for granted that non-Catholics could not accede to it, even if they did die for their country. The Rules for Remaining a True Christian Soldier would remind them how to behave and not to lose their own faith, and thus, to go to heaven after death. The behavior demanded in the section regarding the examination of one's conscience involved saying morning and evening prayers, taking part in Sunday Mass, receiving

\footnotetext{
21 [Carlo Massaruti], Manuale religioso del soldato (Tivoli: Tipografia Tivoli, 19135).

22 [Massaruti], Manuale, 12.

23 Ibid., 19. In the language of intransigent Catholicism, "human respect" was seen as the pride of modern man, who did not want to recognize God and the church's supremacy over national and international politics and society.

24 Ibid., 50-51.
} 
communion and making Confession at least once a year, and, again, not fearing to be open about one's religious feelings.

Other instructions were more directly linked to military life. One prescribed replacing all books that openly spoke against Christian morality and religion with "good and useful books which can educate the brain and most of all the heart to those two sacred and inseparable loves: religion and homeland." Another reminded soldiers that "obedience and respect owed to superiors, alongside discipline, were their principal military duties." Another still defined the Army as "a great family" whose members had to respect and help one another mutually. Finally, one said that every soldier had to love his own uniform and, by his own conduct, make sure it was loved by all citizens. ${ }^{25} \mathrm{~A}$ strong link was therefore established between faith's truth, as learned from the Gospel, and catechism; between the obedience due to God and that due to the sovereign and one's military superiors. ${ }^{26}$

Blasphemy was defined an "awful and ignominious vice," an "insult to the people's faith," a "form of antisocial conduct," "unpatriotic behavior, because it degrades the country in front of other nations," and an "anti-military' fault, because the military code requires one 'to respect Religion, the clergy and all things sacred."'27 Following this speech, one could find the Christian soldier's calendar with the liturgical year and the listing of all the military saints. In the last pages, there were sacred poems to be sung during meetings, mostly Marian hymns that compared Mary to a "banner of glory," a "fortress and a defence," an "invincible host, arrayed on the battlefield." 28

At the beginning of the booklet, Massaruti inserted a dedication to soldiers, dated October 5,1913 , in which he outlined the conceptual frame within which its prayers and precepts should be read. Here, the relation between religion and motherland was similar to that expressed by La Civiltà cattolica in 1910. He stated that religion, faith, and the church did not contribute in any way to weakening the "love for one's country." Quite the contrary, it would be "strengthened and could encourage acts of heroism when tied to the highest principles of the Christian religion." The Manuale aimed at keeping soldiers' "faith strong, which — in Massaruti's words—is Italy's highest glory." He feared that anticlerical propaganda within the Army could distance Catholic soldiers from their faith, urging them to keep away from anyone who criticized the Catholic religion and its doctrines. ${ }^{29}$

$\begin{array}{ll}25 & \text { Ibid., 74-77. } \\ 26 & \text { Ibid., 77. } \\ 27 & \text { Ibid., 84-85. } \\ 28 & \text { Ibid., 97-98, 101. } \\ 29 & \text { Ibid., 4. }\end{array}$


The twelfth edition of the booklet was published in 1915, after Italy entered the war, ${ }^{30}$ with a preface entitled "To the Catholic Soldier." This was taken from another booklet entitled Il soldato di Dio and published by the Lega Eucaristica-founded in Milan by the discalced Carmelites at the end of the nineteenth century. ${ }^{31}$ Similarly to the 1913 edition, it tackled the issue of confession and Holy Communion for soldiers during their constantly exposed and dangerous life. Not by chance, emphasis was put on the importance of confession for soldiers' salvation. ${ }^{32}$ After Italy joined the war, a debate broke out among Italian Catholics regarding the relation between death at war and access to eternal life. ${ }^{33}$ The Holy See distanced itself from the idea that dying for one's country was equivalent to martyrdom, and would therefore be sufficient to ensure entry to heaven regardless of the "hero's" moral and religious behavior during his lifetime. ${ }^{34}$

The 1915 edition also had an appendix entitled "How to Organize Religious and Military Meetings," as well as new songs and prayers, which expressed a sort of patriotism in conformity with that accepted by the Holy See and by $L a$ Civiltà cattolica. One of the songs was a prayer to God and his Sacred Heart, that invoked safety for Italy, but only on a moral level, asking for forgiveness, charity and mercy, while no request was made for a political and military victory. Therefore, the devotion shown to the Sacred Heart was linked to love for one's country, but without the nationalistic overtones it had been charged with in other parts of Europe since the beginning of the war. ${ }^{35}$ In other prayers, forgiveness was asked from the Sacred Heart for those who had abandoned faith and had openly disdained God. ${ }^{36}$ The persistent request for forgiveness and repentance, in particular of those who had distanced themselves from

30 "Ai soldati d'Italia!," in [Carlo Massaruti], Manuale religioso del soldato (Roma: Officina Poligrafica, $\left.1915^{12}\right), 3-5$.

31 On the Lega Eucaristica, see Maria Paiano, "Culto eucaristico e restaurazione di una società cristiana”: 'L'Aurora del secolo del sacramento' sotto il pontificato di Leone XIII," Rivista di storia del cristianesimo 2 (2005): 95-131.

32 [Massaruti], Manuale (1915): 7-10.

33 Marcello Malpensa, "Il sacrificio in guerra nelle lettere pastorali dell'episcopato," Humanitas 63 (2008): 905-24.

34 See Benedict XV, "Incruentum altaris," August 10, 1915, Acta Apostolicae Sedis 7 (1915): 401-5 and Maria Paiano, "Benedetto Xv e la preghiera durante la Grande Guerra: Il caso italiano," Schweizerische Zeitschrift für Religions- und Kulturgeschichte 108 (2014): 259-78, here $268-74$.

35 Daniele Menozzi, Sacro cuore: Un culto tra devozione interiore e restaurazione cristiana della società (Rome: Viella, 2001), 255-81; Sante Lesti, Riti di guerra: Religione e politica nell'Europa della Grande Guerra (Bologna: Il Mulino, 2015).

36 [Massaruti], Manuale (1915), 44-45. 
God, was coherent with the Holy See's interpretation of the war as a divine punishment for society's apostasy from the church. ${ }^{37}$ Thus, the booklet's patriotism was part of a strategy of moralization and re-Christianization of soldiers and, through them, the re-Christianization of the Army and of all society. Nonetheless, the duty to fight and to die for the motherland was in no way denied. The Prayer for our dear ones that have left for the war did not ask for peace, but only confirmed this duty and called for the protection of the families of those who had gone to war. ${ }^{38}$

Massaruti's ideas on homeland and religion, as outlined in the 1915 edition, ${ }^{39}$ also appeared in many letters written by Jesuit chaplains and priest-soldiers of the Roman Province. Massaruti himself was not only engaged in "updating" the booklet after Italy entered the war. Even though he was never appointed chaplain or mobilized as a priest-soldier, since 1914 he began intensifying his activities among the soldiers of the so-called "inner front" near Rome, particularly in railway stations, hospitals, and prisons. He had strong links with such committees, associations, and institutions as the Military Curia directed by Bartolomasi and the Comitato Nazionale di Assistenza Religiosa per i Soldati chaired by the aristocrat Isabella Borghese, which worked on similar issues. ${ }^{40}$ But Massaruti had chosen the military apostolate as his own field of engagement even before the war had begun. When Italy entered the war many of his brethren were suddenly confronted with the military world and had to redefine the very aims of their religious vocation. Examining L'Eco dei nostri militari might help us understand how the Jesuits of the Roman Province redefined their vocation and came to terms with mobilization and war itself.

On February 8, 1915, as the Italian involvement in the war drew near, the five Jesuit provincial fathers made a "supplication" to the pope asking for his permission to ordain as priests the Jesuit students who were attending the third year of the theological studies. Their aim was to avoid their older students

37 Daniele Menozzi, Chiesa, pace e guerra nel Novecento: Verso una delegittimazione dei conflitti religiosi (Bologna: Il Mulino, 2008), 15-46.

$38 \quad$ [Massaruti], Manuale (1915), 106-7.

39 We found few references to its circulation among soldiers: Giuseppe Montanari (soldier), letter from Bologna, February 13, 1917, in L'Eco dei nostri militari (hereafter L'Eco) (May 8, 1916): 7 .

40 AIPSJ, Il Padre Carlo Massaruti, 142; Massaruti, P. Carlo Massaruti, 37-41. 
being called up for military duty, and to have them assigned to the medical services (as had been the case until then). ${ }^{41}$ The fathers took full responsibility for completing the students' education after the end of the war, and controlling their religious and moral conduct. The pope, considering the circumstances, accepted their request. ${ }^{42}$

As the provincial superiors had expected, when Italy entered the war all Jesuits considered as "fit" to give service were involved in the country's general mobilization. ${ }^{43}$ By October 1915, 118 priests, students, and lay brothers of the Italian Society had been mobilized for the war: thirty-seven belonged to the Roman Province, thirty-four to the Neapolitan, eight to the Sicilian, twentyfour were from Turin, and nineteen came from the Veneto. There were twentysix priests, half of whom were appointed chaplains and, in the majority of cases, were assigned to medical services. As the provincial superiors had hoped, most of them were appointed to non-fighting assignments. ${ }^{44}$

All of this information was published in the first number of L'Eco dei nostri soldati (soon after renamed L'Eco dei nostri militari), which collected the correspondence of all the province (in conformity with the oldest traditions of the Society $)^{45}$ and was circulated among other Jesuits. ${ }^{46}$ As mentioned before, in the very first article of the first number of the $E c o$ (which circulated in manuscript) it was specified that this was a "private bulletin," and this was regularly repeated in the first page of all of the following numbers. ${ }^{47}$ This meant that it

41 Morozzo Della Rocca, La fede, 125-26. A similar practice had been adopted in France for those priests ordained before 1905: Flageat, Les jésuites, 71.

Archivum Secretum Vaticanum (hereafter ASv), Segreteria di Stato, War 1914-18, file 477, n. 3869 : letter of all the five provincials of the Society in Italy to the pope (Ottavio Turchi, Rome Province; Gaetano Romano, Sicilian Province; Antonio De Francesco, Neapolitan Province; Francesco Calcagno, Turin Province; Gioacchino D. Alberti, Venetian Province), Rome, February 8, 1915; draft of a letter of the Secretariat of State to Turchi, Rome, February 18, 1915, and his answer to the Secretariat, Rome, February 22, 1915.

43 C.B., "I gesuiti della provincia romana nella guerra 1915-1918," Gesuiti della provincia romana (1968/4), 16-22, 16, consulted at the AIPSJ, 554.1bis. The total number of the Jesuits of the Roman Province who served during the war as chaplains or priest-soldiers was 106 (twenty-nine fathers, fifty-eight scholastics, nineteen coadjutors): C.B., "I gesuiti della provincia romana nella guerra 1915-1918," 18 . See Martina, Storia, 255-56.

44 See L'Eco dei nostri soldati, 1, October 1915, 6-7.

45 The war correspondence of French Jesuits is one of the main sources in Flageat, Les jésuites.

46 See above. Sometimes the date or the addressee is not specified.

47 "Ai nostri soldati," in L'Eco dei nostri soldati, 1, October 1915, 1-2. 
should only reach those who were part of the order, probably to avoid censorship (to which it was submitted in any case). ${ }^{48}$

The Jesuit scholastic Giuseppe Castellani was entrusted with editing and distributing $L^{\prime} E c o$. He was assigned to the office of the military bishop in Rome, in the Capranica College. Every month, through a notice in the bulletin, Castellani urged his brethren serving at war to regularly inform their superiors about their activities and conditions of life. He wanted to make sure that all the Jesuits of the province received the bulletin and, therefore, asked everyone to communicate any change in their address. ${ }^{49}$

The reason for this was explained in a letter published in November 1915 and written by Provincial Ottavio Turchi. He believed that the circulation of news among all members of the order would bring comfort and provide a counterweight to any deviations from spirituality, given the context of war. ${ }^{50} \mathrm{He}$ insisted that his fellow Jesuits would only pursue, in spite of the war, the aims of the order's tradition: personal sanctification and achieving the "Society's good." He reminded his readers of those Practical Rules for the Religious Orders Involved in Military Life, set out in 1911 by the Vatican Congregazione dei Religiosi, which required all mobilized clergy to keep away from dangerous entertainments, meetings, and the press. They were also to accomplish—as regularly as possible - all the tasks that were required of them, and to keep in touch with their superiors at all times. These regulations were very similar to those prescribed by the Society itself. He then ended his letter by trying to link the trauma of experiencing war to the order's tradition, recalling the pioneering role that the Society had played in establishing the first military chaplaincies in the sixteenth century, with the aim of edifying and converting armies through their own "apostolate by example." This was introduced by Loyola himself, before he abandoned military life:

The example of your life, your virtues, and your profession, should be a tacit but effective apostolate for your companions' good. In 1587, we were entrusted by Farnese with the military mission in Belgium, and Father Sailly was its first Superior. In 16oo, our missionaries went with the soldiers as far as Ostend; in 1604, the convert Demetrius also wanted them as missionaries of his army in Poland; in 1712, the Catholic soldiers of Valais

48 Letter of the soldier Igino Pomeranzi (coadjutor), May, L'Eco, 20-21, May-June 1917, 13.

49 C. B., "I gesuiti," 17.

5o For an analysis of these arguments in the letters of other religious orders, see Morozzo Della Rocca, La fede, 252, note 16. 
asked for and obtained a missionary who then resided with them during four months of war, and was a brother of ours from the college at Brig. As Saint Ignatius, when he was a soldier of the King of Castile's Army, promoted purity and faith's integrity, so should you, who are his sons, be apostles. ${ }^{51}$

In another letter to the Roman Jesuits, Turchi would again use Ignatius and his life prior to his conversion as a model of the perfect Christian soldier, connecting his use of violence to a "just cause" and emphasizing "the piety, the Catholic zeal, the selflessness, the spirit of conciliation, the clemency in forgiving offences, the nobility with which he bore the harshness of the battle field and the pain of his injuries." 52

This was the model by which the mobilized Jesuits (and not only those of the Roman Province) lived their experience of war, trying to win the masses back to true Christian faith. This is particularly evident in the letters of those Jesuit soldiers that had been assigned to non-fighting services. ${ }^{53}$ The success of their efforts was based not only on their own personal achievements, but also on their companions' behavior and their involvement in religious activities, services, and devout practices. They would try to accomplish this by simply living among them, comforting them in moments of despair, and assisting them when they were wounded. For instance, on September 1, 1915, Angelo Papa wrote from the front that he had managed to stop his companions' blasphemies simply by reciting rosary. ${ }^{54}$ On October 10, 1915 the corporal Silvio Benassi (a scholastic appointed as a regimental instructor), after having observed that he had not obtained many "victories" in his "Christian campaigns"

$5^{1}$ Ottavio Turchi, "Lettera del Reverendo P. Provinciale ai PP. e FF. che prestano il servizio militare (Lettera ad uso esclusivamente privato)," L'Eco, 2, November 1915, 1-2. For Sailly, see Vincenzo Lavenia's "Introduction" to this thematic issue.

52 Ottavio Turchi, "Lettera del Reverendo P. Provinciale ai PP. e FF. che prestano il servizio militare (Come manoscritto ad uso esclusivamente privato)," December 24, 1915, L'Eco, 4, January 1916, 1-2.

53 The addresses of the Jesuits published on the bulletin in February 1916 show that all of them were chaplains or soldiers engaged in the medical services. Among these they were also all the coadjutor brothers and fifty percent of the scholastics of the Roman Province: "Indirizzi dei PP. e FF. della Provincia romana che prestano servizio militare," L'Eco, 5, February 1916, 7-8.

54 Letter of the soldier Angelo Papa (scholastic), September 1, 1915, L'Eco, October 1915, 3. Cf. the letter of the coadjutor Tursi of the Neapolitan Province, Bononia's Hospital, August 16, 1915, L'Eco, October 1915, 5 . 
(in his barrack his companion soldiers had stopped singing obscene songs, but only a few had gone back to a regular observance of the sacraments), he stated that "soldiers would benefit more from good example than the active work of a soldier-apostle, especially when the ground was not suitable."55 For some, the apostolic aim of correcting behavior of one's own companions was itself an encouragement to personal sanctification. The scholastic Giuseppe Chiti stated that "giving people a good example, and [...] contributing to the Society of Jesus's good name" was "a very strong encouragement to conform my actions and my words to the teaching received in the peace of religious life," thus confirming what the provincial fathers had defined as the duties of Jesuits in the Army. ${ }^{56}$

Also, in the letters of Jesuit chaplains, the example of good behavior was seen as an important means through which to reinforce Christian influence over the soldiers. More than the organization of regular services and collective prayer, apostolic successes would result from living in close quarters with soldiers-above all on the battlefront and in dangerous situations. ${ }^{57}$ The bulletin underlined this aspect by publishing communiqués regarding the medals of honor and military value achieved by those Jesuits who had braved danger to assist the soldiers on the front lines. ${ }^{58}$

The correspondence in L'Eco underlined the positive results of the Jesuits' activity. ${ }^{59}$ The writers described soldiers and officials as being usually welldisposed towards them. ${ }^{60}$ Moreover, they would sometimes refer to episodes

55 Letter of Corporal Silvio Benassi (scholastic) to the Provincial, October 10, 1915, L'Eco, November 1915, 4-5. Letter of Francesco Fazioli (scholastic) to Castellani (scholastic), $L^{\prime} E c o$, October 1915, 5 .

$5^{6}$ Letter of Paolo Chiti (scholastic) to the Provincial, November 25, 1915, L'Eco, 3, December 1915,6 .

57 Letter of Salimei, Royal Ship Etna, April 16, 1917, L'Eco, 20-21, May-June 1917, 1-2.

$5^{8}$ Medals for military value were conferred on the chaplains Luigi Poletti (Roman Province), Ernesto Pisacane and Giulio Milone (Neapolitan Province): L'Eco, 25, October 1917, 8; L'Eco, 29, March 1918, 7; L'Eco, 28, February 1918, 8.

59 "L'Ospedale militare di Villavecchia presso Mondragone," December 18, 1915, L'Eco, 4, January 1916, 2-3.

6 Letter of the soldier Domenico Fabi (scholastic), May 9, 1916, L'Eco, 9, June 1, 1916, 7; (without author or date), "Dall'ospedale militare di riserva n. 8 Collegio Germanico," L'Eco, 11, August 1916, 4-5. Chaplain Lorenzo Tognetti, fourth Medical Corps of the Army train of the Order of the Knights of Malta, L'Eco, 5, February 1916, 2-3. Cf. L'Eco, 8, May 1916, 2; letter of Private Savino Sassara (scholastic), Città di Castello, April 11, 1917, L'Eco, 20-21, May-June 1917, 6-7; Chaplain Ottorino Luigi Pastorini, war zone, October 1, 1917, L'Eco, 25, October 1917, 1-3; letter of some in-patients of the Field Hospital Eight in Rome to the chaplain Ercole Jannelli (who worked there), January 6, 1918, L'Eco, 28, February 1918, 7-8, 
of soldiers returning to the Christian faith or even to conversion from other religions. ${ }^{61}$ Throughout the war, in $L^{\prime} E c o$ the general belief was that the war itself had caused a "religious awakening," at least on the battlefront. Some would explain this with the deep rooting of Catholicism in the Italian people (a widespread idea in national Catholic culture). ${ }^{62}$ Others saw the war as an extraordinary occasion through which the country could be re-Christianized, starting with the Army itself. In a letter of August 1916, the chaplain Lorenzo Tognetti, who worked on the hospital-train of the Knights of Malta, quoted the archbishop of Pisa Cardinal Pietro Maffi (1858-1931) to underline the positive role played by military chaplains:

The war is an evil, but it has also made a lot of people change their mind. It has given many a chance to learn about their moral and religious duties, as well as the way to behave in a more Christian fashion for the rest of their lives. As you can tell, I'm very optimistic about this! Recently, Cardinal Maffi has rightfully said: military chaplains today have the flower of the country in their own hands. Let them rejoice if they can save it $!^{63}$

here 8. Some anticlerical attitudes emerged from the correspondences: letter of Private Pomeranzi (scholastic), Cervia, November 6, 1917, L'Eco, 26, December 1917, 6-7.

61 Navy Chaplain Raffaele Lallai, "Tra gente di mare," Brindisi, L'Eco, 11, August 1916, 2-3. Cf. the letters from a protestant and a catholic soldier, L'Eco, 20-21, May-June 1917, 2-3, here 3. Similar situations also emerged in some letters of Jesuits of the other Provinces published in L'Eco: Chaplain Domenico Piemonte (Province of Veneto) to the Father Assistant, Asinara (where he was chaplain of prisoners of war), March 16, 1916, L'Eco, 8, May 1916, 1-2. Cf. Domenico Piemonte, May 7, 1916, L'Eco, 9, June 1, 1916, 1-2 and letter to Father Piero Tacchi Venturi, Asinara, July 8, 1916, L'Eco, 11, August 1, 1916, 1-2.

62 "Nell'Ospedale di Villavecchia (Frascati-Mondragone)," L'Eco, 12, September 1916, 1-2, here 2. On the connection between religion and homeland in the Italian Catholic world from the second half of the nineteenth century onwards Francesco Traniello, Religione cattolica e stato nazionale: Dal Risorgimento al secondo dopoguerra (Bologna: Il Mulino, 2007), and Guido Formigoni, L'Italia dei cattolici dal Risorgimento a oggi (Bologna: Il Mulino, $\left.2010^{2}\right)$.

63 Tognetti, August 1916, L'Eco, 12, September 1916, 2-4, here 3-4. See the letters of Private Angelo Tomé (scholastic), L'Eco, 12, September 1916, 6, and the letters of Sergeant Pio Scatizzi (father), Orvieto, August 31, 1916, L'Eco, 13, October 1916, 7. A similar optimistic spirit can be found in an article that characterizes the increasing favor for the military chaplains as "a justification of the only religion able to give the strength necessary to face even the hardest deprivations": “I cappellani militari nell'esercito italiano," La Civiltà cattolica 67 (1916/2): 202-8, 330-8, 421-31, here 333. Some scholars cast doubt on the authenticity of the "religious awakening" in the country and on the front: Alfonso Prandi, "La guerra e le sue conseguenze nel mondo cattolico italiano," in Benedetto XV, i cattolici e 
Tognetti also saw the British occupation of Jerusalem on December 9, 1917 as a step towards re-Christianization of the whole of society. He defined that military action as a "return to Christendom for those parched Holy Lands," and organized a small celebration in its honor. His words seem to imply the idea that European civilization was so deeply rooted in Christianity that it could still be defined as "Christendom," and the divisions between Christians were, therefore, a superficial and transitory phenomenon. ${ }^{64}$

The supremacy of the apostolic aspiration (both as sacerdotal sanctification and as re-Christianization of society) meant that patriotic tones and statements were very few in number in the bulletin. Moreover, after the pope sent his letter entitled Al tremendo conflitto to Cardinal Basilio Pompili (1858-1931), on March 4, 1916, arguing in favor of a universal peace by a "spiritual mobilization," more and more letters in L'Eco would express the desire to find peace on any terms possible (that is, not necessarily through victory). ${ }^{65}$ Before the autumn of 1917, only a few letters expressed strong and/or emphatic patriotism, and seldom addressed the political considerations that had led Italy into war. For example, on February 5, 1916 the corporal Stefano Scorza, a scholastic, stated: "Suffering for the motherland is a matter of glory. This is in my heart!." 66 The Sacred Heart was invoked by Jesuit soldiers not on behalf of the homeland, but rather for miracles and for protection in moments of danger. Not even during the Army's consecration to the Sacred Heart on January 5, 1917 did patriotic stances emerge, and the enthusiasm of many for the ceremony, promoted by the Franciscan Agostino Gemelli (1878-1959), was connected, rather, to the soldiers' requests to receive confession and the Holy Communion.

Some Jesuits who were part of the fighting troops could even see the war from an aesthetic perspective. This was the case for Second Lieutenant Tordella, who, in a letter of March 7, 1916, wrote:

You should see the beautiful effect shrapnel makes when it explodes in mid-air and grenades that raise a great deal of earth and stones that sometimes reach our trenches; luckily the Austrians do not always achieve

la prima guerra mondiale, ed. Giuseppe Rossini (Rome: Cinque Lune, 1963), 153-205, here 174-75.

64 Tognetti, December 25, 1917 and January 1, 1918, L'Eco, 27, January 1918, 2-3, here 3.

65 Letter of Private Raffaele Bitetti (scholastic), Udine, March 7, 1916, L'Eco, 7, April 1916, 3; Tognetti, Udine, May 8, 1916, L'Eco, 9, June 1916, 4.

66 Letter of Corporal-Major Stefano Scorza (scholastic), L'Eco, 7, April 1916, 1-2. Cf. Scorza, December 6 and 8, 1915, L'Eco, 4, January 1916, 4; Scorza, April 26, 1916, L'Eco, 7, April 1916,3 . 
their goal! Did you read the war bulletin of February 26 ? What an action by our glorious regiment! 67

The editors of the bulletin discreetly tried to guide the mobilized Jesuits' relationship with war by publishing texts that changed military life's dynamics, but also by putting forth the idea of war being "just" and "holy" on an anthropological and spiritual level. In June, it published an Ascetical Note by Monsignor Dubois (translated from the French periodical Prêtres aux armées) that posited a connection between the life of soldier and human life in general, both characterized by labor, hard work, danger, and struggle. Human life was described as a constant war, fought on a moral and religious level, but still a real war. This was because men were always surrounded by enemies they had to defend themselves from. Men should, therefore, conquer a "kingdom" for themselves and fight spiritually, because "this war isn't only just, but holy: God has imposed it on us, and wants our sanctification in every day's fight; he is our ally; his grace is our support." One should pray to God to be armed "for the fight with the virtues of the saints," and to receive "strength and courage in His [God's] service." ${ }^{8}$ These ideas were close to those of both the pope and of La Civiltà cattolica, which, since the beginning of the war, had been trying to limit manifestations of patriotism by Catholics not only in Italy, but in all other countries at war. ${ }^{69}$

\section{4}

\section{After Caporetto}

After the rout of Caporetto on October 24, 1917, references to love for one's country became more and more frequent and explicit in the letters of Jesuit chaplains. Nonetheless, the pre eminence of their religious duties was never questioned. The letters of Ottorino Luigi Pastorini, chaplain of the ninth regiment of the Lancers of Florence, are particularly significant. On December 5, 1917, writing from the battle lines, after having won back many of his companions to his pastoral care, he declared: "I have gathered all the sheep that

67 Gaetano Tordella (scholastic), March 7, 1916, L'Eco, 14, November 1916, 3-4. See the letters of Sergeant Nazareno Rossi (coadjutor), October 1916, and of Private Giuseppe Montanari, Bologna, November 2, 1916, both coadjutor brothers, L'Eco, 15, December 1, 1916, 5-6. Cf. soldier Luigi Fiorentini, June 16, 1917, L'Eco, 22-23, August 1917, 13-14.

68 Monsignor Dubois, "Militia Christi': La milizia cristiana," L'Eco, 9, June 1916, 8.

69 Maria Paiano, "La preghiera e la guerra in Italia durante il primo conflitto mondiale," $\mathrm{Hu}$ manitas 63 (2008), 925-42; Paiano, Benedetto XV. 
I have brought back to Religion and to a more devout love for the homeland,"70 and then described the Mass he had celebrated on November 18 (probably the first after the defeat), in which he emphatically linked religious and patriotic elements. In this open-air Mass, the altar was placed in the middle of a field between two flags and two crossed lances that had been positioned before and behind it. The squadrons were dressed in their battle uniforms and armed with lances. The regiment's standard was carried to the altar accompanied by sounding trumpets, and throughout the ceremony it was held by an officer who stood on the right of the colonel. Before the Mass started, the latter addressed a "fervent speech" to his fellow soldiers "praising their work of valor and abnegation for their country's good; urging them to new enterprises; ending with a very noble invocation to the God of armies." During the Mass, Pastorini addressed the soldiers with a heartfelt speech. He made no mention of "patriotism," but at the end of the ceremony "all the officers, from the colonel to the last lieutenant, vied with each other to shake their chaplain's hand, who, even though he had only expounded Jesus Christ's Word, had not forgotten the loved homeland, praying for a divine blessing to come down on it and urging the soldiers to give of their utmost" for their country.

During the weeks that followed, Pastorini's work of spiritual assistance intensified, with the approval of the military authorities. He created a school for illiterate soldiers, gave daily speeches to the troops, and also obtained a formal recognition by the army officials, receiving statements of great esteem and spiritual endorsement. ${ }^{71}$ During Easter celebrations, he gave the soldiers a memento dedicated "to my Lancers" in which the duties of religion were seen as a support and said to give comfort for the fulfilment of the duties owed to one's country. ${ }^{72}$

The relationship envisaged by the Jesuits between religion and motherland underlined the strength that one would find from the former to fight for victory of the latter. This was coherent with what Military Bishop Bartolomasi would say in his speeches, sometimes published in the same bulletin, ${ }^{73}$ and also emerges from the letters of some of the Jesuit soldiers. On January 19, 1918, Private Graziani wrote that he felt at his ease knowing he was doing "God's will" and his own duty, and invoked the Virgin to help him "defend the country

$70 \quad$ Pastorini, war zone, December 5, 1917, L'Eco, 27, January 1918, 1-2, here 1.

71 Pastorini, war zone, January 27, 1918, L'Eco, 28, February 23, 1918, 2.

72 Pastorini, war zone, April 15, 1918; Corrispondenza (Provincia Romana), June 1, 1918.

73 "Echi di provincia," L'Eco, 6, March 1916, 8; Corporal Ernesto Arrighetti (scholastic), February $27,1917, L^{\prime} E c o, 18$, March 1917, 3-4. 
in this difficult moment," but also to bring him back to the Society "safe and sound. ${ }^{74}$

A greater patriotic emphasis and a certain "aesthetic appreciation" of the war can be found in the speech delivered on January 1, 1918 by the Navy's chaplain Raffaele Salimei, who worked at the base of Brindisi. The occasion was that of the receipt of a flag donated by an aristocratic woman, Marchioness Gabriella Sommi-Picenardi, in memory of her late husband Galeazzo (who had died at sea). The flag was delivered by the admiral of the royal explorer Alessandro Poerio, Alfred Acton. Salimei wanted to send, "with wings of war and of joy," his best wishes for the New Year to all Italian soldiers and sailors, noting that he was making his address from a ship that bore "the name of a soldier, a poet, and patriot that had fallen during the defence of Venice." The new flag represented "war [...], valor and virtue [...], courage and tenacity," because every "sailor and his entire ship should never desist from the commitment they have for their motherland!" Salimei blessed the flag and asked God to bless the Italian Fleet and the whole of Italy. Moreover, he added that "the motherland's banner" belonged to heaven and when lifted up in battle, sailors would look at it "as a symbol of faith, and a vision of the prize that awaited them." ${ }^{5}$

In Salimei's speech, love for his country was in no way limited by his religious views and by the obligations they implied. Furthermore, the speech was published in its full version in the Notices and News, and in the introduction of the bulletin Salimei's speech was referred to as "our own." This reflected the indulgence shown by the Holy See after Caporetto towards the display of patriotic feelings by the clergy and lay believers. This was partly the result of the pressure of Italian political and military authorities on the Vatican, during the national emergency that followed the defeat, requesting a big effort on their behalf to raise the troops morale and that of all the people. ${ }^{76}$ However, the reasons why Salimei's speech was published—it was unusual for $L^{\prime} E c o$ to publish letters with strong patriotic feelings - might be better understood if we consider another fact: the growing tension between the Navy chaplain and Monsignor Rodolfo Ragnini (1865-1958), Bartolomasi's vicar for the Navy. What happened between them is not completely clear. Morozzo della Rocca

\footnotetext{
74 Private Camillo Graziani (coadjutor), January 19, 1918, $L^{\prime} E c o, 28$, February 1918, 5.

75 "Avvisi e Notizie," L'Eco, 29, March 1918, 6.

76 On the limits traced by the pope for Catholic patriotism, see A. [Benedict Xv], "La chiesa e i suoi ministri nelle amarezze dell'ora presente," L'Osservatore romano, October 8, 1914, and a secret circular letter to the Italian bishops, May 26, 1915, in the Asv, Segreteria di Stato, War 1914-18, file 63, nn. 6813-14. About the partial change of this line after Caporetto cf. Paiano, Benedetto XV, 273-74.
} 
wrote that Ragnini and Salimei had a disagreement regarding the publishing in the February 1918 edition of La Civiltà cattolica of an essay on Ragnini's collection of war sermons. ${ }^{77}$ In it some of the vicar's expressions were seen as being more fit for the military than for the Gospel, and this opinion was followed by contrasting praise for Giacomo Della Vecchia's volume Brevi discorsi ai soldati. The criticism of Ragnini's sermons becomes more evident when the author, the Jesuit Gervasio Celi, states that Della Vecchia's spiritual sons were "exposed to the gravest of dangers for their souls and bodies, and yet he [Della Vecchia] seizes all, banner, uniform, and companions, to convince the young soldiers to live and die like true Christians." Celi added that, when saying this, Della Vecchia did "not lose himself in useless phrases and in careless and pompous invectives" and, in conclusion, he wrote that the aim of chaplains was "to transform soldiers, who take up earthly arms, into real soldiers of Christ, by aligning their souls with Jesus. ${ }^{178}$ The exact reasons for Ragnini and Salimei's falling-out is unknown, but the essay did appear to condemn the former's sermons for being too patriotic and too military in tone. It implied that Ragnini had forgotten the dominant role of religion and that chaplains had a strictly apostolic mission: the safety of the Christian soldier's soul. It is possible that Salimei was defending $L a$ Civiltà cattolica from Ragnini's strong reaction. Moreover, the speech he gave in January was published in L'Eco in March (a month after the publication in La Civiltà cattolica) and could be seen as a more general sign of the Jesuits' desire to underline the love they felt for their country; this was to be a clear message addressed to the leaders of the Military Curia and the military authorities. ${ }^{79}$

Apart from Salimei and Ragnini's contrast, the directives given by the Roman provincial Paolo Dell'Olio, even after Caporetto, continued to put love for one's own country and dying for the motherland amongst Christian values, though true Christian life had to go further than that (both for laymen and the religious). Above all there was to be a clear difference between political aims (for instance, Italy's reasons for joining the war) and the spiritual aim of building God's kingdom. On Christmas Day 1917, he wrote a letter urging his brothers to help accomplish the plans laid down by the Divine Providence, that he

77 Rodolfo Ragnini, I sermoni della messa festiva detti ai soldati di mare e di terra negli anni 1915-1916-1917 (Vicenza: Società Anonima Tipografica, 1917²). Salimei makes reference to this event in a report of July 2, 1918, quoted in Morozzo della Rocca, La fede, 221-22, note 18. Morozzo, however, does not explain the reasons for the falling-out.

78 [Gervasio Celi], "Rivista della Stampa: Oratoria pei soldati," La Civiltà cattolica 68, no. 1 (1918): 348-51, here 350-51.

Morozzo della Rocca, La fede, 221-22, note 18. 
considered to be linked with "our and other people's sanctification," and with "Jesus Christ and his Church's glorification." He believed therefore that the accomplishment of military duties and sacrifices for the country should not come as a result of political and mundane aims, but for the coming of the kingdom of God, which would not coincide with the victory of either sides at war:

When fighting in the battlefields, assisting the ill and the wounded, and in every other thing you do when serving your community [...], sacrifice yourselves with bravery for your earthly homeland, being certain that through generous obedience you shall receive higher gifts than those promised by the "miserable politics of the world," and that in this way the Kingdom for which every day we pray "adveniat regnum tuum" will advance and grow. ${ }^{80}$

These ideas were expressed in a private context. With few exceptions not much is yet known regarding public attitudes of the Italian Jesuits who had been mobilized during the First World War because of the lack of relevant studies. We can at least say that the Roman Jesuits' ideas on the war, and particularly the directives of their provincials, were in line with the positions expressed by $L a$ Civiltà cattolica. Indeed, the periodical proposed a particular understanding of the conflict, not seeing it only as a divine punishment for modern society's apostasy (a theme that is almost absent in the letters published by $L^{\prime} E c o$ ), but also as an opportunity to re-Christianize it: the apparent "religious awakening" among civil society and the troops seemed to prove this. ${ }^{81}$

This providential meaning given to the war seems to be an important element in the correspondence published by $L^{\prime} E c o$. In the letters of many Jesuits, both the ideas of obeying political authorities and defending one's own country seem to be part of a two-sided project: firstly, a political one, regarding the military victory of the motherland; secondly, a religious one, concerning reChristianization of society. The two projects were interdependent, and neither aspect, at least in the motivations of many of these Jesuit writers, should be regarded as more important than the other.

80 AIPSJ, Paolo Dell'Olio, letter to the brethren of the Roman Province, without title, December 25, 1917, printed booklet, 4-5.

81 Daniele Menozzi, "La cultura cattolica davanti alle due guerre mondiali," Bollettino della Società di studi valdesi 112 (1995): 28-6o, here 35-48. 
